\title{
Uji Antibakteri Nanopartikel Kitosan terhadap Pertumbuhan Bakteri Staphylococcus aureus dan Escherichia coli. \\ (Antibacterial Test of Chitosan Nanoparticles against Staphylococcus aureus and Escherichia coli)
}

\author{
Alce K. Magani*, Trina E. Tallei, Beivy J. Kolondam \\ Program Studi Biologi, FMIPA Universitas Sam Ratulangi, Manado 95115 \\ ${ }^{\star}$ Email korespondensi: alcemagani@gmail.com
}

(Article History: Received 30-12-2019; Revised 15-01-2020; Accepted 23-01-2020)

\begin{abstract}
Abstrak
Antibakteri merupakan zat yang dapat menghambat pertumbuhan bakteri dan dapat membunuh bakteri penyebab infeksi. Staphylococcus aureus dan Escherichia coli merupakan bakteri Gram positif dan Gram negatif yang dapat menimbulkan infeksi atau penyakit dalam tubuh. Penelitian ini bertujuan untuk menguji aktivitas bakteri patogen dengan memakai nanopartikel kitosan sebagai antibakteri yang dibuat dalam empat konsentrasi $(0,5 \%, 1 \%$, $1,5 \%$ dan $2 \%$ ) serta penggunaan kontrol asam asetat 1\%, ciprofloxacin dan air steril sebagai pembanding. Metode penelitian yang digunakan yaitu metode gelasi ionik untuk pembuatan nanopartikel kitosan dan difusi agar untuk pengujian antibakteri. Data dianalisis dengan One Way Anova yang dilanjutkan dengan metode BNT (Beda Nyata Terkecil). Hasil penelitian diperoleh penghambatan pertumbuhan bakteri S. aureus dan E. coli tertinggi pada konsentrasi $0,5 \%$, dengan diameter zona hambat hari pertama sampai hari ketiga $12,31 \mathrm{~mm}, 9,98 \mathrm{~mm}$, dan $20,46 \mathrm{~mm}$ pada $S$. aureus dan $15,88 \mathrm{~mm}, 18,71 \mathrm{~mm}$, dan $20,43 \mathrm{~mm}$ pada $E$. coli, kategori kuat, dan bersifat bakteriostatik dan penghambatan terendah pada konsentrasi $2 \%$ dengan diameter zona hambat pada $S$. aureus yaitu $5,56 \mathrm{~mm}, 5,50 \mathrm{~mm}$, dan $5,40 \mathrm{~mm}$, dan pada $E$. coli yaitu 5,93 mm, 9,64 mm, dan 12,58 mm, kategori sedang, dan bersifat bakteriostatik.

Kata kunci: Kitosan, nanopartikel kitosan, aktivitas antibakteri.
\end{abstract}

\section{Abstract}

Antibacteria is a substance that can inhibit the growth of bacteria and able to kill bacteria that cause infections. Staphylococcus aureus and Escherichia coli are Gram positive and Gram negative bacteria that able to cause infections or diseases. This study aimed to examine the activity of pathogenic bacteria by using chitosan nanoparticles as antibacterial. The treatments were made in four concentrations $(0.5 \%, 1 \%, 1.5 \%$ and $2 \%)$ and, for comparison, there were also acetic acid control, ciprofloxacin and sterile water. The research method used is the ionic gelation method for the manufacture of chitosan nanoparticles and agar diffusion for antibacterial testing. Data were analyzed with One Way Anova followed by LSD (Least Significant Difference) method. The results showed the highest inhibition of growth of S. aureus and $E$. coli bacteria at a concentration of $0.5 \%$, with a diameter of inhibition zones of the first day to the third day of $12.31 \mathrm{~mm}, 9.98 \mathrm{~mm}$, and $20.46 \mathrm{~mm}$ in S. aureus and 15,88 $\mathrm{mm}, 18,71$ $\mathrm{mm}$, and 20,43 $\mathrm{mm}$ in E. coli, the strong category, and are bacteriostatic and the lowest inhibition was at $2 \%$ concentration with inhibition zone diameters in S. aureus namely 5.568 $\mathrm{mm}, 5.50 \mathrm{~mm}$, and 5, $40 \mathrm{~mm}$, and in E. coli, $5.93 \mathrm{~mm}, 9.63 \mathrm{~mm}$ and $12.58 \mathrm{~mm}$, the medium category and bacteriostatic.

Key words: Chitosan, nanoparticles chitosan, antibacterial activity.

\section{PENDAHULUAN}

Bakteri penyebab infeksi dan penyakit banyak ditemui di lingkungan sekitar kita termasuk bakteri Staphylococcus aureus dan Escherichia coli yang juga merupakan bakteri Gram positif dan Gram negatif. Penyakit pneumonia, luka, radang paruparu, dan endokarditis atau sepsis adalah infeksi dan penyakit yang dihasilkan oleh bakteri S. aureus (Angelica 2013). Bakteri 
ini dapat bertahan hidup pada lingkungan yang mengandung garam dengan konsentrasi yang tinggi. Bakteri $S$. aureus mudah berkembangbiak karena dapat bertumbuh pada suhu optimum sekitar $30^{\circ} \mathrm{C}$ (Mustika 2018).

Selain bakteri $S$. aureus bakteri $E$. coli juga merupakan bakteri penyebab infeksi dan penyakit yang bersifat patogen. E. coli ditemukan di dalam usus manusia yang berperan dalam proses pengeluaran zat sisa pada saluran pencernaan dan dapat menginfeksi usus sehingga menimbulkan diare (Puteri dan Milanda 2017).

Pertumbuhan bakteri penyebab infeksi dan penyakit perlu dihambat dengan antibakteri. Antibakteri merupakan zat yang dapat menghambat pertumbuhan bakteri dan dapat membunuh bakteri patogen (Paju et al. 2013). Antibakteri dibedakan menjadi dua yaitu bakteriostatik yang menekan pertumbuhan bakteri dan bakterisidal yang dapat membunuh bakteri (Safitri 2016).

Kitosan memiliki sifat antibakteri yang dapat menghambat pertumbuhan bakteri patogen dan mikroorganisme pemusuk termasuk bakteri Gram positif dan Gram negatif (Hafdani 2011). Adanya polikation yang bermuatan positif kitosan dapat menekan pertumbuhan bakteri penyebab penyakit (Mardy 2016). Kitosan sekarang banyak diolah oleh para ahli menjadi ukuran nanopartikel yang berkisar 100-400 $\mathrm{nm}$.

Kemampuan kitosan yang diolah menjadi nanokitosan memiliki kemampuan adsorpsi yang lebih baik dikarenakan memiliki permukaan yang spesifik dan ukurannya yang lebih kecil (Sivakami et al. 2013). Nanokitosan yang berukuran kecil dapat dengan mudah masuk dalam sel bakteri (Cauerhff et al. 2013).

Beberapa penelitian aktivitas antibakteri nanopartikel kitosan memenfaatkan bahan ekstrak etanol daun pugun tanoh (Picria fel-terrae Lour.) dalam menghambat pertumbuhan bakteri bekerja efektif baik dalam sediaan ekstrak kental maupun dalam bentuk nanopartikel (Mustika 2018). Juga pemenfaatan kitosan dalam produk pangan antibakteri kitosan menunjukkan bahwa konsentrasi $0,5 \%$ dan $1 \%$ kitosan dapat menghambat pertumbuhan bakteri pada ikan asin yang telah dikeringkan dengan aktivitas penghambatan yang baik (Killay 2013).

Aktivitas antibakteri nanopartikel kitosan dalam menghambat pertumbuhan bakteri S.aureus dan E. coli belum pernah dipublikasikan sehingga dilakukan penelitian uji antibakteri nanopartikel kitosan terhadap pertumbuhan bakteri $S$. aureus dan $E$. coli dengan menggunakan metode gelasi ionik dan difusi agar. Penelitian ini bertujuan untuk menguji efektivitas antibakteri nanopartikel kitosan pada pertumbuhan bakteri $S$. aureus dan E. coli.

\section{METODE}

\section{Sterilisasi alat}

Untuk melakukan penelitian, beberapa alat cawan petri, labu Erlenmeyer, jarum Oose, gelas ukur, dan pengaduk magnetik yang digunakan, terlebih dahulu disterilisasi pada suhu $121^{\circ} \mathrm{C}$ selama 15 menit dengan menggunakan autoklaf.

\section{Pembuatan nanopartikel kitosan dengan metode gelasi ionic}

Pembuatan larutan stok, yaitu $2 \mathrm{gr}$ kitosan dilarutkan dengan asam asetat $1 \%$ sampai $100 \mathrm{~mL}$ diaduk pada suhu ruang selama tiga jam pada kecepatan 1500 rpm sehingga didapati konsentrasi $2 \%$ selanjutnya dilakukan pengenceran untuk mendapatkan konsentrasi $1,5 \%, 1 \%$, dan $0,5 \%$ kemudian disterilisasi (pastikan semua konsentrasi memiliki $\mathrm{pH} 6$ ). Pengenceran dibuat menggunakan rumus:

$$
\begin{aligned}
& M_{1} \times V_{1}=M_{2} \times V_{2} \\
& \text { Dimana: } \\
& M_{1}=\text { Konsentrasi awal } \\
& M_{2}=\text { Konsentrasi yang ingin dibuat } \\
& V_{1}=\text { Volume yang diperlukan } \\
& V_{2}=\text { Volume yang akan dibuat }
\end{aligned}
$$

\section{Perlakuan penelitian}

Konsentrasi kitosan yang digunakan adalah $0,5 \%, 1 \% 1,5 \%$ dan $2 \%(\mathrm{w} / \mathrm{v})$, kontrol asam asetat $1 \%$, ciprofloxacin, dan air steril. Pengujian aktivitas antibakteri nanopartikel kitosan dilakukan menggunakan metode difusi agar yang dimodifikasi (Murhadi 2002). 


\section{Pengujian antibakteri nanopartikel kitosan dengan metode difusi agar}

Cawan petri yang dilengkapi pencadang berisikan media NA sebanyak $10 \mathrm{~mL}$ sebagai lapisan pertama dibiarkan hingga mengeras setelah itu penuangan media NA sebanyak $10 \mathrm{~mL}$ yang didalamnya ada bakteri uji sebagai lapisan kedua, setelah itu didiamkan didalam laminar air flow selama dua jam untuk membiarkan media mengeras dan bakteri berdifusi, kemudian pencadang dikeluarkan sehingga diperoleh sumursumur yang berdiameter $5 \mathrm{~mm}$. selanjutnya penuangan antibakteri nanopartikel kitosan dan kontrol pembanding kedalam sumur masing-masing sebanyak $200 \mu \mathrm{L}$ setelah itu dimasukkan kedalam inkubator pada suhu $37^{\circ} \mathrm{C}$ selama $3 \times 24$ jam, kemudian dilakukan pengamatan zona bening atau zona hambat setiap 24 jam.

\section{Perhitungan zona hambat}

Zona hambat antibakteri dari nanopartikel kitosan diukur berdasarkan jari-jari $\left(r_{p}, \mathrm{~mm}\right)$ dan penghambatnya berupa areal bening di sekeliling sumur uji. Pengukuran jari-jarinya dilakukan dengan mengukur jarak dari tepi sumur uji ke batas lingkaran zona hambat (ketelitian 0,05 $\mathrm{mm}$ ), pada beberapa sisi sumur uji, lalu dirata-ratakan (Murhadi 2002). Penghitungan luas zona hambat mengikuti prosedur Adam et al. (2014).

$$
\begin{aligned}
& \begin{array}{l}
\text { Rumus, } D=\frac{\mathrm{d} 1+\mathrm{d} 2}{2} \\
\text { Dimana: }
\end{array} \\
& \begin{array}{ll}
\mathrm{D}= & \text { diameter Antibakteri nanopartikel } \\
& \text { kitosan }
\end{array} \\
& \mathrm{d} 1=\begin{array}{l}
\text { diameter vertikal antibakteri } \\
\text { nanopartikel kitosan }
\end{array} \\
& \mathrm{d} 2=\begin{array}{l}
\text { diameter horizontal antibakteri } \\
\text { nanopartikel kitosan }
\end{array}
\end{aligned}
$$

\section{Analisis Data}

Data diambil dari hasil pengamatan dan pengukuran diameter zona hambat pada tiap-tiap konsentrasi antibakteri nanopartikel kitosan. Analisis secara statistic dengan aplikasi SPSS dan microsoft Excel untuk melihat potensi antibakteri nanopartikel kitosan dengan berbagai kosentrasi terhadap pertumbuhan bakteri Staphylococcus aureus dan Escherichia coli.

\section{HASIL DAN PEMBAHASAN \\ Nanopartikel Kitosan \\ Staphylococcus aureus}

Diameter zona hambat diperoleh dari pengamatan aktivitas antibakteri nanopartikel kitosan dalam menekan pertumbuhan bakteri $S$. aureus yang dilakukan selama $3 \times 24$ jam berturut-turut. Hasil menunjukan bervariasi dari masingmasing konsentrasi nanopartikel kitosan dan kontrol pembanding yang dipakai (Tabel 1) . Zona hambat yang diperoleh pada hari pertama lebih tinggi dibandingkan pada saat pengamatan hari kedua.

Tabel 1. Diameter zona Hambat (mm) pada Pengamatan 3×24 Jam pada Uji Antibakteri Nanopartikel Kitosan dengan beberapa Konsentrasi terhadap S. aureus

\begin{tabular}{cccc}
\hline \multirow{2}{*}{ Konsentrasi } & \multicolumn{3}{l}{$\begin{array}{l}\text { Rata-rata diameter zona } \\
\text { hambat }(\mathrm{mm})\end{array}$} \\
\cline { 2 - 4 } & Hari 1 & Hari 2 & Hari 3 \\
\hline $0,5 \%$ & 12,31 & 9,98 & 20,46 \\
$1 \%$ & 9,81 & 8,71 & $1, .77$ \\
$1,5 \%$ & 5,94 & 5,88 & 10,77 \\
$2 \%$ & 5,56 & 5,50 & 5,40 \\
Asam asetat 1\% & 8,89 & 7,90 & 6,83 \\
Ciprofloxacin & 29,22 & 33,39 & 33,10 \\
Air Steril & 0 & 0 & 0 \\
\hline
\end{tabular}

Konsentrasi $0,5 \%$ memiliki daya hambat yang cukup kuat setelah kontrol ciprofloxacin dalam menekan pertumbuhan bakteri uji. Hal tersebut dibuktikan dalam penelitian Killay (2013) bahwa kitosan dengan kosentrasi $0,5 \%$ memiliki daya penghambatan yang kuat.

Konsentrasi $2 \%$ nanopartikel kitosan memiliki daya hambat terendah. Hal ini terjadi karena kandungan kitosan yang dimiliki oleh konsentrasi $0,5 \%$ lebih sedikit dibandingkan dengan konsentrasi $2 \%$ 
(lebih kental), sehingga proses berdifusi konsentrasi $0,5 \%$ lebih baik dibandingkan dengan konsentrasi $2 \%$, dan kemampuan menekan pertumbuhan bakteri ujipun terpengaruh karena cepat lambatnya antibakteri berkerja, hal ini sesuai dengan penelitian yang dilakukan oleh Nurainy et al. (2008).

Analisis statistik one way anova memperoleh hasil bahwa $\mathrm{F}$ hitung $(36,76)$ $>\mathrm{F}$ tabel 5\% (2,84). Hasil tersebut kemudian dilanjuti dengan uji beda nyata terkecil (BNT 5\%) dalam bentuk notasi. Hasil pembuatan notasi konsentrasi 0,5\% berbeda nyata dengan konsentrasi $1,5 \%$, dan kosentrasi $2 \%$ tetapi tidak berbeda nyata dengan konsentrasi $1 \%$. Hal ini dikarenakan kemampuan penghambatan konsentrasi $0,5 \%$ lebih besar dari konsentrasi $1,5 \%$ dan konsentrasi $2 \%$ (Tabel 2).

\section{Tabel 2. Perbandingan uji BNT konsentrasi antibakteri nanopartikel kitosan dan kontrol pembanding dalam menekan pertumbuhan bakteri $S$. aureus.}

\begin{tabular}{ccc}
\hline Konsentrasi & $\begin{array}{c}\text { Rata-rata } \\
\text { diameter }\end{array}$ & Notasi \\
\hline air steril & 0 & a \\
$2 \%$ & 5,49 & b \\
$1,5 \%$ & 7,53 & b \\
asam asetat 1\% & 7,87 & b \\
$1 \%$ & 11,43 & bc \\
$0,5 \%$ & 14,25 & $\mathrm{c}$ \\
Ciprofloxacin & 31,90 & $\mathrm{~d}$ \\
\hline
\end{tabular}

\section{Aktivitas Antibakteri Nanopartikel Kitosan pada E.coli}

Hasil pengujian aktivitas antibakteri nanopartikel kitosan yang dilakukan selama 3x24 jam dalam menekan pertumbuhan bakteri $E$. coli menunjukan variasi nilai diameter tiap konsentrasi. Pengukuran diameter zona hambat sampai pada lama inkubasi 72 jam terus mengalami peningkatan (Tabel 3). Hal ini disebabkan muatan positif dari nanopartikel kitosan berinteraksi dengan muatan negatif membran sel bakteri $E$. coli yang menyebabkan kerusakan membran luar sel dan keluarnya konstituen intaseluler bakteri uji (Suherman et al. 2018; Nurainy et al. 2008).

Tabel 3. Diameter zona hambat $(\mathrm{mm})$ antibakteri nanopartikel kitosan terhadap E. coli pada pengamatan $3 \times 24$ jam.

\begin{tabular}{cccc}
\hline \multirow{2}{*}{ Konsentrasi } & \multicolumn{3}{c}{$\begin{array}{c}\text { Rata-rata diameter } \\
\text { zona hambat }\end{array}$} \\
\cline { 2 - 4 } & $\begin{array}{c}\text { Hari } \\
1\end{array}$ & $\begin{array}{c}\text { Hari } \\
2\end{array}$ & $\begin{array}{c}\text { Hari } \\
\end{array}$ \\
\hline $0,5 \%$ & 15,88 & 18,71 & 20,43 \\
$1 \%$ & 12,61 & 14,84 & 18,42 \\
$1,5 \%$ & 9,50 & 12,71 & 15,65 \\
$2 \%$ & 5,93 & 9,64 & 12,58 \\
Asam asetat & 6,59 & 7,11 & 6,19 \\
$1 \%$ & 32,73 & 41,07 & 34,69 \\
Ciprofloxacin & 3 & 0 & 0 \\
Air Steril & 0 & 0 & \\
\hline
\end{tabular}

Daya hambat tertinggi pada konsentrasi $0,5 \%$ sedangkan daya hambat terendah yaitu konsentrasi $2 \%$. Hal ini dikarenakan kandungan kitosan konsentrasi $2 \%$ lebih kental dari konsentrasi $0,5 \%$ sehingga proses penghambatan pertumbuhan bakteri $E$. coli melambat karena proses berdifusi dalam media NA yang berisi bakteri uji cukup lama dibandingkan konsentrasi $0,5 \%$ yang penghambatannya bekerja lebih baik dan sangat kuat dalam menekan pertumbuhan bakteri E. coli.

Nilai diameter yang diperoleh dilanjutkan dengan menganalisis statistik one way anova dengan tujuan melihat perbandingan antara $\mathrm{F}$ hitung dan $\mathrm{F}$ tabel $5 \%$. Hasil analisis one way anova menunjukan bahwa nilai $\mathrm{F}$ hitung $(51,19)>$ F tabel 5\% (2,84). Hasil ini membuktikan bahwa adanya perbedaan secara signifikan pola penghambatan dari tiap konsentrasi sehingga dilanjutkan dengan uji beda nyata terkecil (BNT 5\%), dalam bentuk notasi untuk melihat perbedaannya (Tabel 4).

Hasil uji BNT 5\% memperlihatkan bahwa konsentrasi $0,5 \%$ berbeda nyata dengan konsentrasi $2 \%$, dan kosentrasi $1,5 \%$, tetapi tidak berbeda nyata dengan 
konsentrasi 1\% Hal ini disebabkan penghambatan yang diperoleh dari konsentrasi $0,5 \%$ lebih besar dari konsentrasi $2 \%$, dan konsentrasi $1,5 \%$, akan tetapi meskipun konsentrasi $1 \%$ juga memiliki kemampuan penghambatan pertumbuhan bakteri $E$. coli lebih kecil dari kosentrasi $0,5 \%$ namun hal tersebut tidak membuktikan bahwa keduanya berbeda secara nyata setelah dilakukan pengujian BNT 5\%,

Tabel 4. Uji BNT 5\% antibakteri nanopartikel kitosan pada E. coli.

\begin{tabular}{ccc}
\hline Konsentrasi & $\begin{array}{c}\text { Rata-rata } \\
\text { diameter }\end{array}$ & Notasi \\
\hline Air Steril & 0 & $\mathrm{a}$ \\
$\begin{array}{c}\text { Asam asetat } \\
1 \%\end{array}$ & 6,63 & $\mathrm{~b}$ \\
$2 \%$ & 9,38 & $\mathrm{bc}$ \\
$1,5 \%$ & 12,62 & $\mathrm{~cd}$ \\
$1 \%$ & 15,29 & $\mathrm{de}$ \\
$0,5 \%$ & 18,34 & $\mathrm{e}$ \\
Ciprofloxacin & 36,16 & $\mathrm{f}$ \\
\hline
\end{tabular}

\section{Perbandingan Daya Hambat Antibakteri Nanopartikel Kitosan pada Staphylococcus aureus dan Escherichia coli}

Berdasarkan pengujian antibakteri nanopartikel kitosan terhadap bakteri $S$. aureus dan $E$. coli diperoleh hasil bahwa kemampuan antibakteri nanopartikel kitosan kitosan bekerja lebih efektif dalam menekan pertumbuhan bakteri $E$. coli dibandingkan pada $S$. aureus. Hal ini dibuktikan dalam penelitian Suherman et al. (2018), bahwa kitosan mempunyai muatan positif yang kuat yang dapat mengikat muatan negatif dari senyawa lain atau berperan dalam menghambat pertummbuhan bakteri karena sifat utamanya adalah antibakteri.

Proses penghambatan antibakteri nanopartikel kitosan lebih tinggi dan terus meningkat dalam inkubasi selama $3 \times 24$ jam dalam penekanan pertumbuhan bakteri $E$. coli dibandingkan bakteri $S$. aureus setelah kontrol ciprofloxacin
(Gambar 1). Penghambatan teringgi pada konsentrasi $0,5 \%$, dan penghambatan terendah pada konsentrasi $2 \%$, baik pada E. coli ataupun pada S. aureus. Hal ini telah dibuktikan oleh penelitian Nurainy et al. (2008), dimana konsentrasi lebih kecil memiliki potensi lebih besar dalam menghambat pertumbuhan bakteri.

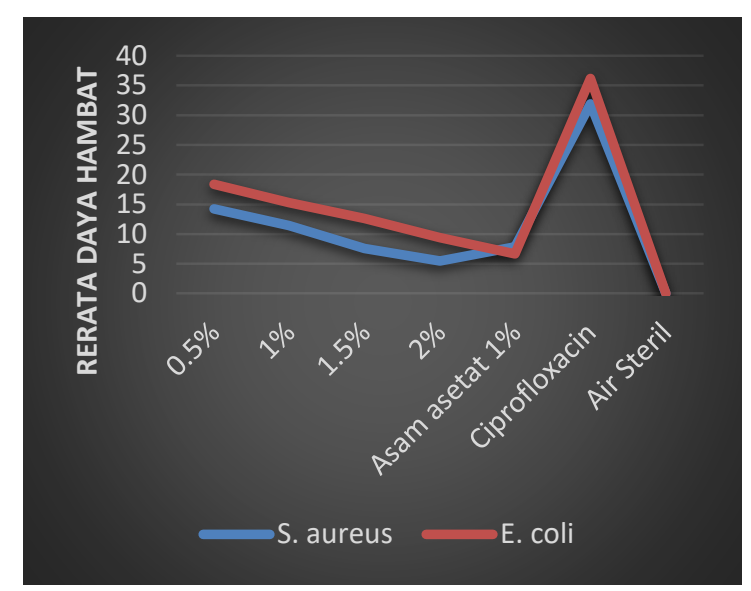

Gambar 1. Grafik Perbandingan S.aureus dan E.coli

Hasil pengujian antibakteri dari nanopartikel kitosan dapat dikatakan berhasil dalam menekan pertumbuhan bakteri penyebab infeksi dan penyakit atau bakteri patogen pada lama pengujian selama 3x24 jam. Hal ini mendukung pernyataan Hafdani (2011) dan Killay (2013), bahwa kitosan memiliki sifat antibakteri dan juga berpotensi untuk menekan pertumbuhan bakteri patogen yang termasuk antibakteri bakteriostatik.

\section{KESIMPULAN}

Konsentrasi antibakteri nanopartikel kitosan dapat menghambat pertumbuhan bakteri Staphylococcus aureus dan Escherichia coli. Penghambatan yang terbesar terhadap pertumbuhan bakteri yaitu konsentrasi $0,5 \%$ yang memiliki kemampuan menghambat atau daya hambatnya bekerja sangat baik dibandingkan dengan konsentrasi lainnya. Zona hambat yang dihasilkan oleh antibakteri nanopartikel kitosan bekerja lebih efektif dalam menghambat bakteri $E$. coli dibandingkan dengan $S$. aureus. Antibakteri nanopartikel kitosan dalam menghambat pertumbuhan bakteri $S$. 
aureus dan E. coli bersifat bakteriostatik dimana antibakteri ini berhasil menekan atau mencegah pertumbuhan bakteri uji.

\section{DAFTAR PUSTAKA}

Adam AA, Posangi J, Tumewu E, Tallei TE (2014) Aktivitas antibakteri ekstrak kasar tunikata Polycarpa aurata terhadap Streptococcus mutans. Dentire J 3(2):118-122.

Angelica N (2013) Aktivitas Antibakteri Ekstrak Etanol Daun dan Kulit Batang Kayu Manis (Cinnamomum burmannii (Nees \& Th. Nees)) terhadap Escherichia coli dan Staphylococcus aureus. Calyptra 2(2):1-8.

Cauerhff A, Yanina, NM, German AI, Guillermo RC (2013) Nanotoxicology and Nanomedicine. Chapter 2. New York: Springer.

Hafdani FN, Sadeghinia N (2011) A Review on Application of Chitosan as a Natural Antimicrobial. World Academy of Science. Engineering and Technology.

Harahap Y (2012) Preparasi dan Karakterisasi Nanopartikel Kitosan dengan Variasi Asam. Fakultas Teknil UI. Depok.

Killay A (2013) Kitosan sebagai Antibakteri pada Bahan Pangan yang Aman dan Tidak Berbahaya. Prosiding FMIPA Universitas Pattimura.

Lay BW, Sugyo H (1992) Mikrobiologi Edisi ke satu. Jakarta: Cetakan kesatu. Rajawali Press.

Mardy DC, Sudjari S, Rahayu SI (2016) Perbandingan Efektivitas Kitosan (2Acetamido-2-Deoxy-D-

Glucopyranose) dan Nano Kitosan terhadap Pertumbuhan Bakteri Enterococcus faecalis secara In Vitro. Majalah Kesehatan FKUB 2(4):229240.

Murhadi (2002) Isolasi dan Karateristik Komponen Antibakteri dan Biji Atung
(Parinarium glaberrium Hassak). Program Pascasarjana IPB, Bogor.

Mustika N (2018) Pembuatan Nanopartikel dari Ekstrak Etanol Daun Pugun Tanoh (Picria fel-terrae Lour) dan Uji Antibakteri terhadap Staphylococcus aureus dan Escherichia coli. Fakultas Farmasi Universitas Sumatera Utara. Medan.

Nurainy F, Samsul R, Yudiantoro. (2008) Pengaruh Konsentrasi Kitosan terhadap Aktivitas Bakteri dengan Metode Difusi Agar (sumur). Jurnal Teknologi Industri dan Hasil Pertamina 13(2):120-124.

Paju N, Yamlean PV, Kojong N (2013). Uji Efektivitas Salep Ekstrak Daun Binahong (Anredera cordifolia Steenis.) pada Kelinci (Oryctolagus cuniculus) yang Terinfeksi Bakteri Staphylococcus aureus. Pharmacon 2(1):51-61.

Puteri T, Milanda T (2017) Uji Daya Hambat Ekstrak Daun Lidah Buaya (Aloe vera L.) terhadap Bakteri Escherichia coli dan Staphylococcus aureus. Farmaka, 14(2):9-17.

Safitri AU (2016) Aktivitas Antibakteri Nanopartikel Kitosan Berbasis Cangkang Lobster terhadap Bakteri. Staphylococcus aureus dan Staphylococcus epidermidis. FPIK IPB. Bogor

Sivakami MS, Thandapani, G (2013) Preparation and Characterization of Nano Chitosan for Treatment Wastewaters. In journal of biological macromolecules 57:204-211.

Suherman B, Muhdar L, Sisilia TRD (2018) Potensi kitosan kulit udang vannemei (Litopenaeus vannamei) sebagai antibakteri terhadap Staphylococcus epidermidis, Pseudomonas aeruginosa, Propionibacterium agnes, dan Escherichia coli dengan metode difusi cakram kertas. Jurnal Media Farmasi. 14(1):124-125. 